Lucrările Seminarului Geografic Dimitrie Cantemir

Vol. 45, October 2017, pp. 55-62

http://dx.doi.org/10.15551/lsgdc.v45i0.05

\title{
From communism to post-socialism: land use dynamics in Eastern Romania. Study case: Mogoșești Commune
}

\author{
Silviu Doru ${ }^{1}$, Adrian Andrei ${ }^{1}$, Mihai Niculiță ${ }^{1}$ \\ ${ }^{1}$ Alexandru Ioan Cuza University of Iasi, Romania.
}

To cite this article: Doru, S., Andrei, A., Niculiță, M. (2017). From communism to postsocialism: land use dynamics in Eastern Romania. Study case: Mogoșești Commune. Lucrările Seminarului Geografic Dimitrie Cantemir, Vol. 45, pp. 55-62. DOI: 10.15551/lsgdc.v45i0.05

To link to this article: http://dx.doi.org/10.15551/lsgdc.v45i0.05 


\title{
FROM COMMUNISM TO POST-SOCIALISM: LAND USE DYNAMICS IN EASTERN ROMANIA. STUDY CASE: MOGOȘEȘTI COMMUNE
}

\author{
Silviu Doru ${ }^{1}$, Adrian Andrei ${ }^{1}$, Mihai Niculiță ${ }^{1}$
}

\begin{abstract}
Comprehensive studies that characterize the variation in land use patterns for small comunities across transitional societies are lacking. This paper examines how the political-economic changes in eastern Romania has affected a representative commune from Iași county. According to the results of this analysis, the land reform applied after 1989 presents an increase in land fragmentation and the developement of settlements on the other side of the agricultural and foret landscapes we can observe a renaturation of land use to pastures and forests development. Our analyis on land use can provide a basis for land assessment at small scale and give some aspects for a policy response at a larger scale.
\end{abstract}

Keywords: land use dynamics, post-socialism, renaturation, landscape

\section{Introduction}

Land resources represent an important support in the economic life for the majority of people in the world. The way people handle and use the land potential is decisive for their social and economic well-being as well as for the sustained quality of land resources (Fazal S., 2013). Historically, communities have settled in areas that ensure safety and natural resources necessary for the development of their collectivity.

From the beginning of the agricultural society, land-use decisions have been influenced by limitation regarding soils, distance, productivity, etc. These patterns have been referred to as "traditional" landscapes (Antrop M., 1997), but in the Eastern Europe in the last half of the twentieth century the communist regime has influenced these patterns by reclaiming all the land in the property of the state.

Since the $19^{\text {th }}$ century, the context of Land Reform (Organic Law 1831-1832), proposed to increase agricultural production. In the framework of the land reform attention is given to the situation of rural communities. Around this time for the first time there appears the idea of systematization of villages, the houses that were gathering dispersed over great distances depending on individual farms adjacent land (Vorovenci I., 2003).

Mogoșești commune is located at the contact of two units of relief (Central Moldavian Plateau and Jijia Hills). The landscape in this area has been modified steadily over time. Thus the lower part characteristic for Jijia hills began to be used in agriculture while the higher area from the south, with a relatively fragmented relief has been maintained in its natural condition characterized by the presence of grassland and forest.

\footnotetext{
${ }^{1}$ Alexandru Ioan Cuza University of Iasi, Faculty of Geography and Geology, silviudoru89@ gmail.com Alexandru Ioan Cuza University of Iasi, Faculty of Geography and Geology, andrei_adrian9@yahoo.com
} 
In terms of spatial planning, settlements occupy lands which are less favorable farming and this reflects the fact that soil resources are used rationally. The current appearance of the land use is influenced entirely by landforms present on its territory, this being an essential criterion concerning the dynamics of land use.

More-over, a bias in the landscape coherence is added by the actions and local general public opinion on how to use the land in order to achieve the best benefits from it. In this paper we aimed to explore how the changes of the politic regime after 1989 have influenced the land use from a typically hilly commune of Iași County, eastern Romania. We overlay two landuse maps of 1979 and 2008 with one topographical map, to analyze the changes in land-use associations. Our quantitative analysis is followed by a more in-depth qualitative analysis of how a selection of such associations has evolved.

\section{Data and methods}

\section{Study area}

The analyzed territory is located in the south part of Iași County, about $16 \mathrm{~km}$ away from the county's residence. Mogoșești commune has an area of $67.23 \mathrm{~km}^{2}$ and it is composed of four villages: Budești, Hadâmbu, Mânjești and Mogoșești (communal residence) and it is characterized by a complex relief.

Actually, there are three sectors of relief: Jijia Hills (I), Central Moldavian Plateau (III), separated by Iasi Cuesta (II). However the study area has an altitudinal range of 80 to $350 \mathrm{~m}$ above sea level (Fig. 1).

The mean annual temperature is around of $9^{\circ} \mathrm{C}$ and the mean annual precipitations range from $450 \mathrm{~mm}$ to $500 \mathrm{~mm}$, depending on the elevation and the geographical position. The soils from this area are represented by chernozems and luvisols.

\section{Data collection}

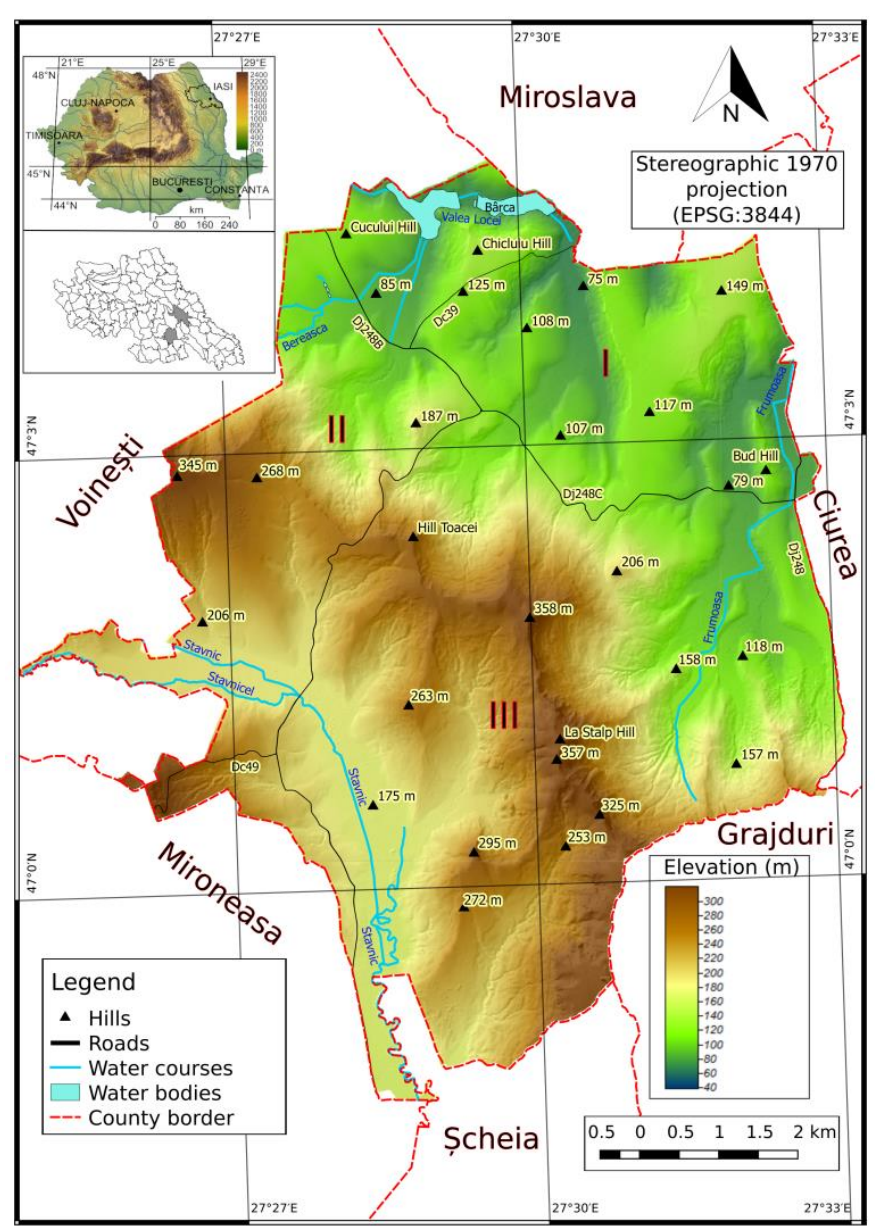

Figure 1 Study area

The first land inventory was created based on cadastral surveys (1979) from basic topographic plans on a 1:2000 and 1:10000 scale. (Fig.2 a) This demonstrated its value for the economic sectors with large areas of land (agriculture, forestry, transport, localities' planning), 
but also for the provision of graphic support for cadastral works by the derivation of its contents (Cadastral Information System 2009).

For 2008 we used an orthophotomap with a spatial resolution of $0.5 \mathrm{~m}$. This approach possesses some advantages for mapping land use and for further view it was validated with the data from Google Earth Historical Imagery (Fig.2 b).

\section{Data processing}

All data collected were georeferenced in Projection Stereo 70, Datum S-42 Romania. During this stage we noticed local errors which appeared in the phase of creating the maps or during scans. The errors (shifting) were corrected with the aid of a reference map.

The ground control points for georeferencing are map elements that can be recognized in both data records, and that supposedly cannot change their position over a long period of time, (e.g. a road intersection, a church or some other sacred object, as they are taken to be landscape objects that have remained relatively unchanged, unlike other more dynamic landscape elements), leaving their intersections relatively intact over a long period of time (Tucek, 1998).

Cadastral surveys maps were georeferenced with GIS software, and we used the affinity type of georeferencing, to diminish the distortion of angles and lengths.

The second spatial land use inventory we applied the technique of orthophotos mapping, a similar approach previously applied on cadastral maps.

All types of land use were classified according the Romanian cadastral land use.

Using Saga-GIS and Arc Map software we created two databases for each period of land use analysis. Statistical analysis was developed in Saga-GIS and Microsoft Excel for a good understanding of the spatial distribution of land use and of changes that occurred between 1979 and 2008.

\section{Results}

We chose this study area because it overlaps two major topographical districts from eastern Romanian. The analysis periods (1979 and 2008) were considered because each one represents the land policy of two different political regimes.

General trend in land use dynamics from Mogosesti commune is represented by notable changes regarding the spatial evolution in both ways either negative or positive. One of the bias that was noticed consist in loses of 41 ha dominated by arable land in the favor of northern administrative unite.

Arable land is divided into a large number of parcels. Moreover, around 290 ha of the arable land become pasture by abandoning or it is conversed in other classes of land use. As a general rule, arable lands are the main areas preferred for the development of settlements.

Another notable change in the structure of land use is the increase in the surfaces of pastures with $6.83 \%$. This has occurred through abandonment and degradation of vineyards and orchards which in time turned into pastures. Large-scale abandonment of less fertile arable land has occurred in Europe since the middle of the 20th century (Sojneková.2015, Rounsevell 2006), but in Romania this phenomenon has increased significantly during the post-socialism period on account of the financial problems of the owners of land. 
Tabel. 1 Surface changes between major land use classes form Mogosesti commune

\begin{tabular}{|c|c|c|c|c|c|c|}
\hline Land use & $1979(\mathrm{Ha})$ & $1979(\%)$ & $2008(\mathrm{Ha})$ & $2008(\%)$ & Difference (ha) & Difference (\%) \\
\hline Arable & 2104.9 & 31.10 & 1792 & 26.64 & -312.9 & -4.46 \\
\hline Pasture & 738.8 & 10.92 & 1193.5 & 17.75 & 454.7 & 6.83 \\
\hline Grassland & 332.7 & 4.92 & 8.7 & 0.13 & -324 & -4.79 \\
\hline Orchard & 106.3 & 1.57 & 0.6 & 0.01 & -105.7 & -1.56 \\
\hline Vineyard & 43.9 & 0.65 & 2.6 & 0.04 & -41.3 & -0.61 \\
\hline Forest & 2534.8 & 37.46 & 2648 & 39.37 & 113.2 & 1.92 \\
\hline Water Bodies & 84.6 & 1.25 & 54.7 & 0.81 & -29.9 & -0.44 \\
\hline Roads & 27.9 & 0.41 & 74.2 & 1.10 & 46.3 & 0.69 \\
\hline Settelments & 776.9 & 11.48 & 878.1 & 13.06 & 101.2 & 1.58 \\
\hline Degraded Land & 16.6 & 0.25 & 73.1 & 1.09 & 56.5 & 0.84 \\
\hline
\end{tabular}

In the study it was observed a decrease in the occupied areas of grassland. These may have been influenced by two issues: wrong classification in the 2008 land use inventory or the period when the aerial images were collected.

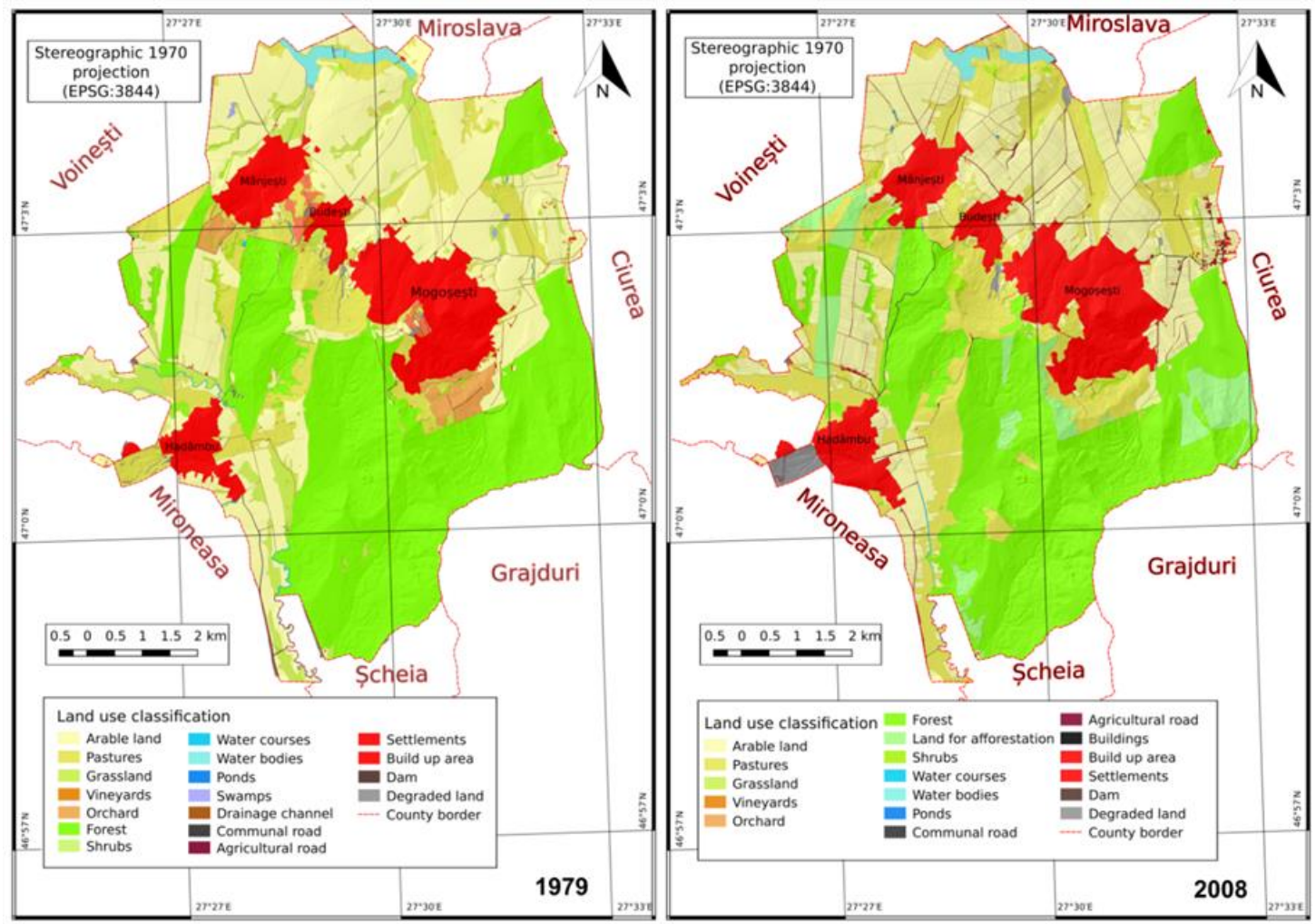

Figure 2 Land use inventory (a) 1979, (b) 2008

In the socialist period, permanent crops (vineyards and orchards) were the results of the maximum exploitation of land surface. In the post-socialism period one of the major changes in the policy of land market was the restitution to former owners. This policy was applied in 13 out the 25 ex-communist countries and has been among the main land reform approaches (Hartvigsen M. 2014). High costs for maintenance of vineyards and orchards and the poverty 
of former owners led to the abandonment of 145 ha of permanent crops. While a part of permanent crops have been transformed into pastures.

Forest areas are mainly located in the Central Moldavian Plateau (III), and were represented by 2648 hectares in 2008. In fact the surfaces of forest increased by $1.92 \%$ compared to 1979 when they represented 2534 ha. The increase in the forest areas is associated with the afforestation of degraded lands after 1980 or natural forest regeneration.

The evolution of water bodies recorded a negative balance that can be explained by the different spatial resolution of the materials used in the study. It should be noted the sedimentation of lakes or drainage channel, that increased the process of land degradation after the passage of private property in 1991.

One major change in land use in Mogoșești commune is the growth of roads. In 1979 the roads accounted for an area of 27.9 ha, reaching 74.2 ha in 2008, recording an increase of $46.3 \%$. Several agricultural roads, from first period were impossible to collect, so this may be a cause for the increase in road surfaces, hence the restitution of land towards the former owners may be a solid argument regarding the increasing number of agricultural roads.

Expansion of degraded lands is caused by intensive soil erosion processes alongside with intensive grazing pastures. Often degraded pastures are interfered with gullies or landslides. Degraded surfaces have increased from 16.6 ha in 1979 to 73.1 ha in 2008, an increase of $0.84 \%$, this posing big questions regarding the management of pastures and intensive grazing pastures.

A final result of our research concerning land use dynamics is the evolution of human settlements from Mogosesti commune. Settlements are individualized by increasing surface area from $11.48 \%$ in 1979 up to $13.6 \%$ in 2008 (Fig. 3).

By applying the changes detection method, we identified two essential changes in the development of Mogosesti settlements. First of all, $0.38 \%$ of the buil-up area which relates to the year 1979 disappeared. The losses of built up area of Manjesti and Mogosesti settlements were caused by landslides that occurred between the years 1970-1973, the effects manifesting in the coming years. Another cause of withdrawal settlements is the social factor, aging population and the abandonment of properties.

On the other side, the withdrawal of settlements is based on social causes. Commune Mogoșești settlements gained by $1.17 \%$ compared to 1979 (Fig.3). After 1990, the population dynamics/exodus from city to village has been caused in some cases by job loss or retirement. In the recent period has developed a new neighborhood, Mogoșești-Șanta near County Road Dj 248, prompted by the quick access to the city of Iași.

\section{Discussion}

Over the last 30 years, we identified spatial and temporal land use changes in Mogosesti commune. The threshold transition from socialism to post-socialism provided numerous changes in the structure of the commune Mogosesti.

The period after 1989 seems to coincide with a decline in socio-economic assets and periods when the institutional capacity to support land managers through a crisis has also declined (Fraser, 2009).

Our results indicate high levels concerning the abandonment and fragmentation of arable land, increase pasture areas and considerable reduction of permanent crop areas. 
According to (Hartvigsen, 2014), there are two fundamentally different aspects of land fragmentation of agricultural land, fragmentation of ownership and land use fragmentation.

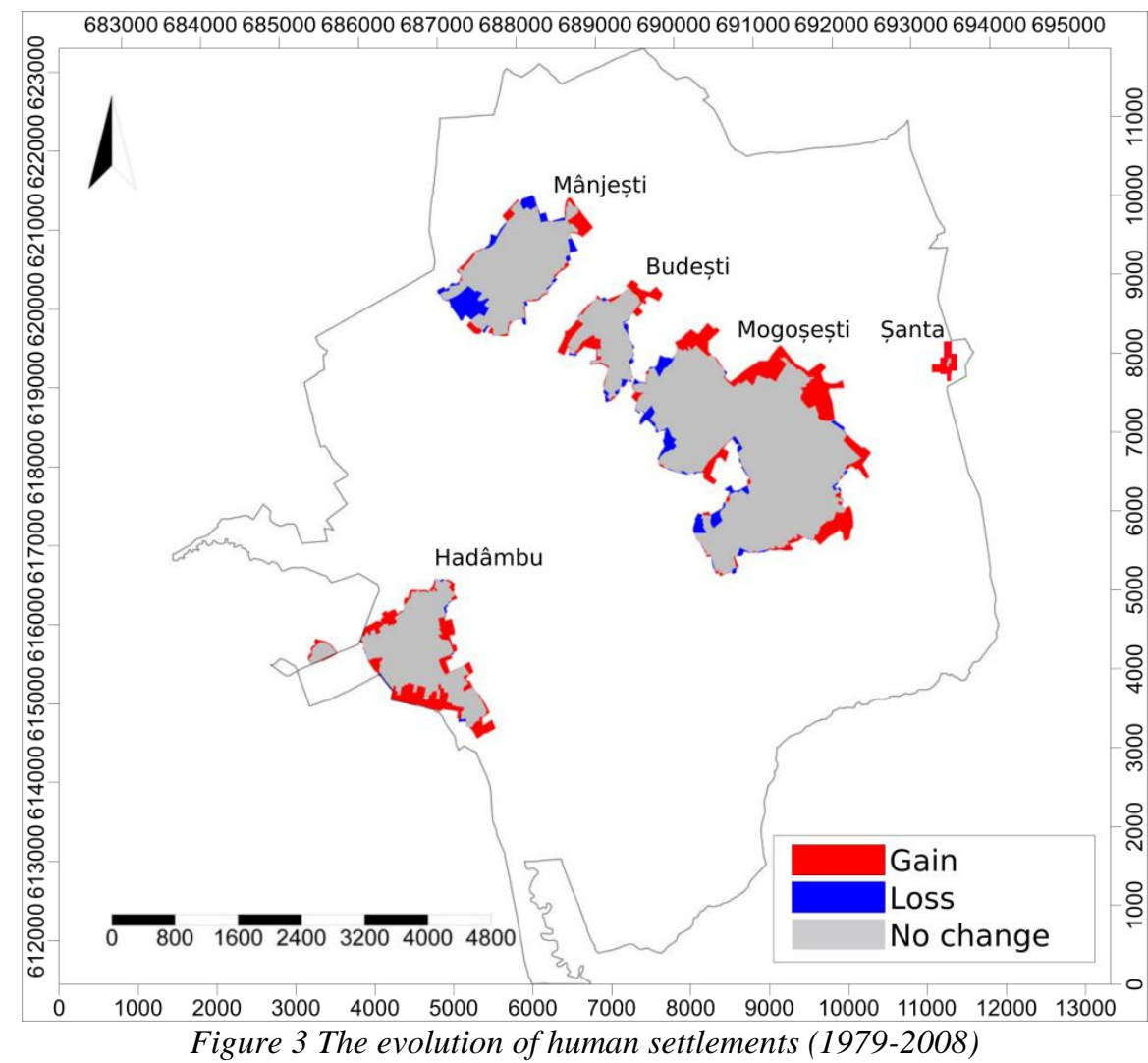

A repossession of landowners in conformity with the law number 18/91 without any kind of support, technological, economic, legislative framework has led to a collapse of agriculture, including small farms. The population of the commune carries out agricultural activities with low economic value, which are determined by the low economic and technological possibilities available to them. Thus, it requires making an optimal plan management of the Land Fund to help the community development.

The expansion of settlements must be made in accordance with a General Urban Plan. Often new built-up areas have developed in flood plains or areas devoid of infrastructures.

\section{Conclusions}

Our study highlights the impact of political and economic decision in the field of land use in the last three decades. Most of changes are caused by lack of vision and uncontrolled evolution of land resource.

Taking into consideration the concept of sustainable development, the further development of land found should pass from the subsistence agriculture, which is dominated by small-scale crop farmers that represents around 60 percent from the farming structure of the agricultural land area (Rusu M., 2002), to a competitive agriculture. 
The further development of the land use scheme should be supported on an exhaustive project that will contain a proper analysis of the natural assets that will take into consideration soil resources and population needs to maintain a balance of human-nature.

\section{Acknowledgment}

We used the computational facilities given by the infrastructure provided through the POSCCE-O 2.2.1, SMIS-CSNR 13984-901, No. 257/28.09.2010 Project, CERNESIM (L4).

\section{References}

1. Antrop M., 1997.The concept of traditional landscapes as a base for landscape evaluation and planning. The example of Flanders Region, Landscape and Urban Planning 38 (1/2), 105-117.

2. Cadastral Information System a resource for E.U. policies 2009 part III (133 - 152)

3. Fazal S., 2013. Land use dynamics in a developing economy, Regional perspectives from India 1-5.

4. Fraser E., Stringer L., 2009. Explaining agricultural collapse: Macro-forces, micro-crises and the emergence of land use vulnerability in southern Romania, Global Environmental Change, 4553.

5. Hartvigsen M., 2014. Land reform and land fragmentation in Central and Eastern Europe, Land Use Policy, 330-341.

6. Sojneková M., 2015 From arable land to species-rich semi-natural grasslands: Succession in abandoned fields in a dry region of central Europe, Ecological Engineering, 373-381.

7. Rounsevell M., et al. 2006. A coherent set of future land use change scenarios for Europe, Agriculture, Ecosystems and Environment, 57-68.

8. Rusu M., Florian, V., Popa, M., Marin, P., Pamfil, V., 2002. Land Fragmentation and Land Consolidation in the Agricultural Sector - A Case Study from Romania, FAO.

9. Tucek J. 1998. GIS - geographic information systems. Principles and practice. Prague: Computer Press (in Czech).

10. Vorovenci I., 2003. A century and a half of land reform in Romania, Economic Journal, 247-253. 
